\title{
Canine Tyrosine Hydroxylase (TH) Gene and Dopamine $\beta$-Hydroxylase (DBH) Gene: Their Sequences, Genetic Polymorphisms, and Diversities among Five Different Dog Breeds
}

\author{
Yukari TAKEUCHI ${ }^{1}$, Chie HASHIZUME ${ }^{1)}$, Esther Myung Ha CHON $^{2)}$, Yukihide MOMOZAWA ${ }^{1)}$, Koji MASUDA ${ }^{1)}$, \\ Takefumi KIKUSUI ${ }^{1)}$ and Yuji MORI ${ }^{1)}$ \\ ${ }^{1)}$ Laboratory of Veterinary Ethology, The University of Tokyo, Tokyo 113-8657, Japan and ${ }^{2)}$ University of California Davis, School of \\ Veterinary Medicine, One Shields Avenue, Davis, CA 95616, U.S.A.
}

(Received 1 March 2005/Accepted 9 May 2005)

\begin{abstract}
Dopamine and noradrenaline are catecholamine neurotransmitters that are produced by biosynthetic enzymes such as tyrosine hydroxylase (TH) and dopamine $\beta$-hydroxylase (DBH). As a first step to elucidate the genetic background of canine behavioral traits, we selected these genes as targets and sequenced these canine genes, and found that both were highly homologous with those of human beings. Then brain cDNAs derived from ten unrelated Beagles were used to search for polymorphisms in these genes. Four single nucleotide polymorphisms (SNPs) (C97T, G168A, G180A and C264T), one of which (C97T) will cause amino acid substitution in the TH gene, and two SNPs (C789A and A1819G), both of which will cause amino acid substitutions in the DBH gene were identified. The allelic frequencies among five dog breeds (47 Golden Retrievers, 41 Labrador Retrievers, 40 Malteses, 26 Miniature Schnauzers, and 39 Shibas) were examined and found to have significant variation between them with regards to all these SNPs, except for C97T in the TH gene and A1819G in the DBH gene. The polymorphisms of C97T and A1819G were found only in the Shiba. The present results suggest that the polymorphisms of the genes encoding catecholamine biosynthetic enzymes may become important markers for examining the genetic background of behavioral characteristics in dogs.

KEY WORDS: breed difference, DBH, dog, polymorphism, TH.
\end{abstract}

Since a genetic polymorphism related to the dopamine D4 receptor (DRD4) was postulated to be related to the "novelty seeking" behavior [2,9], numerous genetic markers for such behavioral traits have been researched in the human psychiatric field $[1,5,6,17,23,30]$. Most of these markers are on genes coding for neurotransmitters, neuropeptides, neurotropic factors or transcription factors, as well as their receptors, synthetic enzymes and metabolic enzymes. Such research is based on the fundamental concept that one's personality is formed from the activity and/or turnover of such components of the hypothalamo-limbic system. Although this system is thought to be conserved in mammals, few polymorphic markers that could be responsible for the behavioral traits or temperament in the other mammals have been listed up. This situation is no exception in case of dogs even though we can now access various canine genome resources for linkage analysis, i.e. the $1 \mathrm{Mb}$ resolution radiation hybrid map of the canine genome [10], the map of 4249 genetic markers featuring one marker every $900 \mathrm{~kb}$ [3]. Therefore we have tried to search genetic markers that would be related to the behavioral traits in dogs and so far found some single nucleotide polymorphisms (SNPs) in neurotransmitter-related genes [12, 19, 20].

In this study tyrosine hydroxylase (TH) and dopamine $\beta$ hydroxylase $(\mathrm{DBH})$ genes were selected for their possible relation to canine behavioral traits. We sequenced these genes, and searched for genetic polymorphisms in these genes. The TH and DBH are biosynthetic enzymes for the synthesis of catecholamines, such as dopamine and norad- renalin, which are important neurotransmitters for the regulation of motor coordination and emotional status (arousal) in the brain. The TH is the rate-limiting enzyme in the synthesis of catecholamines, and is responsible for the conversion of tyrosine to dopa. Polymorphisms on this gene are reported to be related to human personality [29], mood disorders [16, 18, 35], schizophrenia [22, 38] and essential hypertension [36]. The DBH converts dopamine to noradrenalin. Polymorphisms on this gene are reportedly related to the attention deficit hyperactivity disorder [8, 32], Parkinson's disease [13], and smoking [21] in human beings.

\section{MATERIALS AND METHODS}

The canine homologue sequences of TH and DBH genes were determined by RT-PCR method. The complementary DNA (cDNA) was constructed from mRNA derived from the brain of a Beagle $[12,19,20]$. Consensus primers were designed based on the previously identified sequences of human, mouse, rat and bovine TH (GenBank: NM 000360, M69200, L22651, and M36705, respectively), and human, mouse, rat, equine, and bovine DBH (GenBank: Y00096, S50200, L12407, AB029430, and AF118638, respectively). For the 5' and 3' regions, the rapid amplification of cDNA ends (RACE) methods were applied using the SMART RACE cDNA Amplification Kit (Clontech, U.S.A.; for 5' identification) and the 3'-Full RACE Core Kit (TaKaRa, Japan; for 3' identification). Nucleotide sequences of the canine $\mathrm{TH}$ and $\mathrm{DBH}$ genes were determined by the dye-ter- 
mination method using a DNA sequencer (ABI PRISM 3100 Genetic Analyzer, Perkin-Elmer, U.S.A.) and submitted to GenBank.

Our strategy to find polymorphisms responsible for the individuality of behavioral traits has been to screen coding regions first as they are most likely to be related to their functions. We sequenced the mostly full length of these genes from cDNAs of 10 unrelated Beagles with succeeding primer sets (forward: 5'-CAGGCCGAAGCCATCATG-3' reverse: 5'-TATTGGGATTGTGAGTGGGC-3' for the TH gene, forward: 5'-TCTTCCTGGTCATCCTGGTG-3' reverse: 5'-TATGGCTCTTGCAGAGCTCC-3' for upstream part of the DBH gene and forward: 5'-GATGGCCAAGAGATAGAGATCG-3' reverse: 5'-CAGCACACCAACACAGATCG-3' for downstream part of the DBH gene), in order to find polymorphisms in these genes. PCR was performed with $100 \mathrm{ng}$ of cDNA in a $100 \mu \mathrm{l}$ reaction volume, which consisted of $200 \mu \mathrm{M}$ of dNTPs, $10 \mu l 10 \times$ Ex Taq Buffer, $0.3 \mu \mathrm{M}$ of each primer, and 1.25 units of TaKaRa Ex Taq (TaKaRa). After an initial denaturation at $95^{\circ} \mathrm{C}$ for $5 \mathrm{~min}$, PCR was performed using 35 successive cycles of $95^{\circ} \mathrm{C}$ for $60 \mathrm{sec}, 64^{\circ} \mathrm{C}$ for $30 \mathrm{sec}$, and $72^{\circ} \mathrm{C}$ for 60 sec. Chain elongation at $72^{\circ} \mathrm{C}$ was extended to 10 min after the final cycle for the TH gene. PCRs for both upstream and downstream parts of the DBH gene were performed with $100 \mathrm{ng}$ of cDNA in a $100 \mu \mathrm{l}$ reaction volume, which consisted of $200 \mu \mathrm{M}$ of dNTPs, $10 \mu l 10 \times$ Ex Taq Buffer, 0.3 $\mu \mathrm{M}$ of each primer, and 1.25 units of TaKaRa Ex Taq. After an initial denaturation at $95^{\circ} \mathrm{C}$ for $5 \mathrm{~min}$, PCR was performed using 35 successive cycles of $95^{\circ} \mathrm{C}$ for $30 \mathrm{sec}, 54^{\circ} \mathrm{C}$ for $30 \mathrm{sec}$ (for upstream part) or $65^{\circ} \mathrm{C}$ for $60 \mathrm{sec}$ (for downstream part), and $72^{\circ} \mathrm{C}$ for $60 \mathrm{sec}$. Chain elongation at $72^{\circ} \mathrm{C}$ was extended to $10 \mathrm{~min}$ after the final cycle for the $\mathrm{DBH}$ gene.

In order to assess genetic variation in the putative polymorphisms, peripheral blood samples were obtained from 193 individuals of 5 dog breeds (47 Golden Retrievers, 41 Labrador Retrievers, 40 Malteses, 26 Miniature Schnauzers, and 39 Shibas) $[12,19,20]$. Genomic DNA was extracted with the QIAamp Blood Midi Kit (QIAGEN, U.S.A.), dissolved into $\mathrm{H}_{2} \mathrm{O}$, and stored at $4{ }^{\circ} \mathrm{C}$ until PCR was performed. The methods for genotyping the identified SNPs were as follows.

TH gene C97T, G168A, G180A, and C264T: The sequence of the forward primer was 5'-AGCAGGTGCTCACAGACA-3', and the reverse primer was 5'-TGTGTGAGTCCCATGGAGA-3'. PCR was performed with 40 $n \mathrm{~g}$ of genomic DNA in a $100 \mu l$ reaction volume, which consisted of $200 \mu \mathrm{M}$ of dNTPs, $10 \mu l 10 \times$ Ex Taq Buffer, $0.5 \mu \mathrm{M}$ of each primer, and 1.25 units of TaKaRa Ex Taq. After an initial denaturation at $95^{\circ} \mathrm{C}$ for $5 \mathrm{~min}$, PCR was performed using 35 successive cycles of $95^{\circ} \mathrm{C}$ for $60 \mathrm{sec}$, $60^{\circ} \mathrm{C}$ for $60 \mathrm{sec}$, and $72^{\circ} \mathrm{C}$ for $30 \mathrm{sec}$. Chain elongation at $72^{\circ} \mathrm{C}$ was extended to $10 \mathrm{~min}$ after the final cycle. The successfully amplified fragments were directly sequenced and genotyped.

DBH gene C789A: The sequence of the forward primer was 5'-GCTTCTGGCAGATTCTGTGG-3', and the reverse primer was 5'-GGCAGACTTTGAGCTCTTGG-3'. PCR was performed with $30 \mathrm{ng}$ genomic DNA in a $100 \mu \mathrm{l}$ reaction volume, which consisted of $200 \mu \mathrm{M}$ of dNTPs, 10 $\mu l$ of $10 \times$ Ex Taq Buffer, $0.5 \mu \mathrm{M}$ of each primer, and 1.25 units of TaKaRa Ex Taq. After initial denaturation at $95^{\circ} \mathrm{C}$ for $5 \mathrm{~min}$, PCR was performed using 33 successive cycles of $95^{\circ} \mathrm{C}$ for $60 \mathrm{sec}, 60^{\circ} \mathrm{C}$ for $30 \mathrm{sec}$, and $72^{\circ} \mathrm{C}$ for $30 \mathrm{sec}$. Chain elongation at $72^{\circ} \mathrm{C}$ was extended to $5 \mathrm{~min}$ after the final cycle. Genotyping was done by the restriction enzyme fragment length polymorphism (RFLP) method as follows. The PCR product $(35 \mu l)$ was digested with 5 units of HpyCH4 III enzyme (NEB, U.S.A.) and $5 \mu l$ of NEB buffer 4 in a total volume of $50 \mu l$. The products were then electrophoresed on $3.0 \%$ agarose gel in $1 \times \mathrm{TBE}$ to estimate the product size (CC; $361 \mathrm{bp}, \mathrm{CA} ; 361 \mathrm{bp}, 290 \mathrm{bp}$ and $71 \mathrm{bp}$, AA; $290 \mathrm{bp}$ and $71 \mathrm{bp}$ ).

DBH gene A1819G: The sequence of the forward primer was 5'-GGTAAATGGGATCTGCAACC-3', and the reverse primer was 5'-AGGCAGAGCTATTCCACAGG3'. PCR was performed with $30 \mathrm{ng}$ genomic DNA in a 100 $\mu l$ reaction volume, which consisted of $200 \mu \mathrm{M}$ of dNTPs, $10 \mu l$ of $10 \times$ Ex Taq Buffer, $0.5 \mu \mathrm{M}$ of each primer, and 1.25 units of TaKaRa Ex Taq. After initial denaturation at $95^{\circ} \mathrm{C}$ for $5 \mathrm{~min}$, PCR was performed using 30 successive cycles of $95^{\circ} \mathrm{C}$ for $30 \mathrm{sec}, 60^{\circ} \mathrm{C}$ for $30 \mathrm{sec}$, and $72^{\circ} \mathrm{C}$ for 30 sec. Chain elongation at $72^{\circ} \mathrm{C}$ was extended to 5 min after the final cycle. Genotyping was also done by the RFLP as follows. The PCR product $(30 \mu l)$ was digested with 9.6 units of Bgl I enzyme (TOYOBO, Japan) and $5 \mu l$ of $10 \times \mathrm{H}$ Buffer in a total volume of $50 \mu l$. The products were then electrophoresed on $3.0 \%$ agarose gel in $1 \times$ TBE to estimate the product size (AA: $236 \mathrm{bp}, \mathrm{CA}: 236 \mathrm{bp}, 164 \mathrm{bp}$ and $72 \mathrm{bp}$, AA: $164 \mathrm{bp}$ and $72 \mathrm{bp}$ ).

In order to analyze the breed differences of identified SNPs, $\chi^{2}$ tests for independence were used. If the identified SNP was not found in all 5 breeds, the statistics were done using the data from breeds with an identical SNP.

\section{RESULTS}

The genes amplified in this study contained a 1, $488 \mathrm{bp}$ $(\mathrm{TH})$ and $1,878 \mathrm{bp}(\mathrm{DBH})$ open reading frame, and the complete nucleotide sequences of canine TH and DBH cDNAs were submitted to GenBank with the accession numbers of AB097058 and AB097057, respectively. The identified sequences were identical to those obtained from the canine whole genome shotgun sequence that has recently (January 2005) been made available (GenBank; NW_139885 chromosome 18 for TH gene and NW_139867 chromosome 9 for DBH gene). The respective homologies at the nucleotide level of human, mouse, rat and bovine genes were $87 \%, 83 \%, 82 \%$ and $86 \%(\mathrm{TH}) ; 79 \%, 74 \%, 74 \%$, and $79 \%$ (DBH); those at predicted amino acid level were $89 \%, 87 \%$, $89 \%$ and $86 \%(\mathrm{TH}) ; 74 \%, 70 \%, 70 \%$ and $75 \%$ (DBH) (Fig. 1). There is a 16 amino acids insertion in the canine DBH gene at the $527^{\text {th }}$ residue from the first methionine (Fig. 1). 
TH



canine 118 RPRAGGPHLEYFVRGEVPSADL PALLSSVRRVAEDVRGAGENIVLWFPRKVSELDKCHH human 120 RPRAGGPHLEYFVRLEVRRGDLAALLSGVROVSEDVRSPAGPKVPWFPRKVSELDKGHHL mouse 121 RPLAGSPHLEYFVRFEVPGDLAALLSSVRRVSDDVRSAREDKVPWFPRKVSELDKCHHL rat 11 RPLAGSPHLEYFVREVPSGDLAALLSSVRRVAEVRSAREDKVPWFPRKVSELDKGH

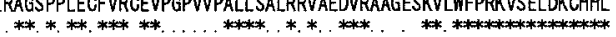

canine 178 VTKFDPDLDLDHPGFSDQVYRQRRKLLIAEIAFGYKHGDPIPRVEYTAEEIATWKEVYTTL human 180 VTKFDPDLDLDHPGFSDOVYRORRKL IAEIAFQYRHGDPIPRVEYTAEEIATMKEVYTTL mouse 181 VTKFDPDLDLDHPGFSDQAYRQRRKL IAEIAFQYKQGEPI PHVEYTKEEIATWKEVYATL bovine 174 VTKFDPDLDLDHPGFSDOAYQRRKL AE AAFQYKHGEPIPHVEYTAEE ATTWEVYSTL

canine 238 KSLYVTHACREHLEAFGLLERFSGYREDSIPQLEDVSRFLKERTGFQLRPVAGLLSARDF human 240 KGLYATHACGEHLEAFALLERFSGYREDNI PQLEDVSRFLKERTGFOLRPVAGLLSARDF mouse 241 KGLYATHACREHLEAFOLLERYGGYREDSI PQLEDVSHFLKERTGFOLRPVAGLLLSARDF $r$ at
bovine 234 KGLLYPTHACREHLEAFELLERFGGYREDRIPQLEDVSRFLKERTGFOLRPVAGLLSARDF

can ine 298 LASLAFRVFGGTOY!RHASSPMHSPEPDCCHELL GHVPML ADRTFAOFSQDIGLASLGAS human 300 LASLAFRVFOCT OYIRHASSPUHSPEPDCCHELL GHVPMLADRTFAQFSQDIGLASLGAS mouse 301 LASLAFRVFGCTOYIRHASSPWHSPEPDCGHELLGHVPMLADRTFAQFSQDIGLASLGAS $r$ at 301 LASLAFRVFCTOY IRHASSPMHSPEPDCCHELLGHVPMLADRTFAQFSODIGLASLGAS bovine 294 LASLAFRVFOCTOYIRHASSPMHSPEPDGCHELLAHGPMLADRTFAOFSODIGLASLGVS

can ine 358 DEEIEKLSTLYWFTVEFGLCKONGEVKAYGAGLLSSYGELLLHSLSEEPEIRAFDPDAAAV human 360 DEEIEKLSTLSWFTVEFGLCKQNGEVKAYGAGLLSSYGELLHCLSEEPEIRAFDPEAAAV mouse 361 DEEIEKLSTWWFTVFGLCKQNGELKAYGAGLLSSYGELHSLSEEPEVRAFDPDTAAV bovine 354 DEEIEKLSTLYWFTVEFGLCKONGEVNAYGAGLLSSYGELLHSLSEEPEIRAFDPOAAAV

canine 418 OPYODOTYGSWYFUSESFSDAKDKLRNYASRIORPFSVKFDPYTLAIDVLDSPHAIRRSL can ine 418 QPYQDQTYGSWYFVSESFSDAKDKLRNYASRI QRPF SWK human 420 QPYQDQTYGSVYVVESFSDAKDKLRSYASRI QRPFSVKFDPYTLALVVDSPQAVRRSL mouse 421 QPYQDQTYGPVYSESFEAKDKLRNYASRIORPF SVKFDPYT LADVLDSPHTIORS bovine 414 QPYQDQTYQPVYFVSESFSDAKDKLRSYASRI ORPFSVKFDPYTLAIDVLDSPHAIRRAL

canine 478 EGVQXELHTLAHALSAIG

human 480 EGVODELDTLAHALSAIG

mouse 481 EGVODELHTLTQALSAIS

rat 481 EGVQDELHTLAHALSAIS

bovine 474 DGVQDEHQALAHALNAIS

\section{DBH}

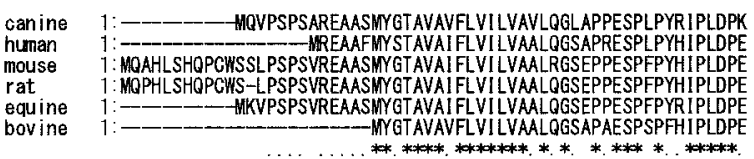

canine 50:GDLELSWDVSYTOKTIYFQLLVOELKAGVLFGMSDRGELENADLWLWTDGDNAYFGDAW human 43:GSLELSWNVSYTQEAIHFQLLVRRLKAGVLFGHSDRGELENADLWLWTDGDTAYFADAW mouse 61:G! LELSWNVSWVEI IHFOLQVOGLRAGVLFGMSDRGEMENADL IMLWSDGDRAYFADAW rat 60:GTLELSWNVSYDQE IIHFQLQVQGPRAGVLFGMSDRGEMENADLVMLWTDGORTYFADAW equine 50:GTLELSWNVSWQET IHFOLLLRELKAGVLFGMSDRGELENADLWLWTDGDSAYFGDAM
bovine 37:GTLELSWNISYADETIYFOL IVRELKAGVL FGMSDRGELENADLVLWTDRDGADFGAW

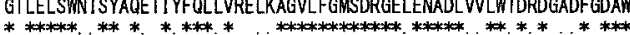

canine 110: SDQRGOIHLDSQQDYQLLRAORTPKGLGLLFKRPFGTCDPKDYF I EDGTVHLVYVLEEP human 103: SDOKGOIHLDPQQDYQLLOVORTPEGLTLLFKRPFGTCDPKDYL I EDGTVHLVYGILEEP mouse 121:SDRKGOIHLDSQQDYQLLQAORTRDGLSLLFKRPFVTCDPKDVI EDDTVHLVYGILEEP rat 120: SDOKGO!HLDTHQDYQLLQAQRVSNSLSLLFKRPFVTCDPKDYVIEDDTVHLVYG!LEEP equine 110: SDOKGWIHLDAQQDYQLLLRAORTPEGLSLLFKRPFGTCDPKDYL IEDGTVHLVYG! LEEP bovine 97 : SDOKGOVHLDSQODYQLLRAQRTPEGLYLLFKRPFGTCDPNDYL I EDGTVHLVGFLEEP

can ine 170:FGSLEAINTSGLOKGL GRVQLLKPKISI PALPEDRRTMDI QAHNVLIPSK-TTYWCHLIK human 163:FRSLEAINGSGLOMGLORVOLLKPNI PEPELPSDACTMEVOAPN I QI PSQETTYWCYIKE mouse 181:FOSLEAINTSGLHTGLLRVGLLKSEVPTPSMPEDVQTMD! RAPDIL IPONEOTYWCYITE rat 180:FOSLEAINTSGLHTGLQQVQLLKPEVSTPAMPADVOTMDIRAPDVLIPSTETTYWCYITE equine 170: FWSLEAINTSALHTGLGRVGLLKPNVSVPALPADMRTMEVRAPDVLVPGOETTYWCYITE
boV ine 157 : LRSLES INTSGLHTGLORVQLLKPSI PKPALPADTRTME I RAPDVLIPGQTTYWCWTE . ***.***.*.**..*****. $* \ldots * * * \ldots * \ldots * \ldots * * \ldots$ can ine 229: LPGDFPRHHIVMYEPI ITKGNEAL VHHI E] FQCINW FFONITSFSGSGDSKEKPQEL LVCR human 223: LPKGFSRHHI IKYEPIVTKGNEALVHHMEVFQCAPEMDSVPHFSGPCDSKMKPDRL NYCR mouse 241:LPPRFPRHHI IMYEAIVTEGNEALVHHMEVFQCAAESEDFPQFNGPCDSKMKPDRLNYCR rat 240.LPLHFPRH bov ine 217:LPDGFPRHHI VWYEPIVTEGNEAL VHHMEVFQGAAEFETI PHFSGPGDSKMKPQRLNFCR $* * * * * * * * * \ldots$ canine 289: HVLAAWALGARAFYYPEEAGLAFGGSNSSRFLLLEIHYHNPTNI RGRYDNSGIRLHYTAK human 283:HVLAAWAL GAKAFYYPEEAGLAFGGPGSSRYLRLEVHYHNPLVI EGRNDSSGIRLYYTAK rat 作 bOV 277. 277: HVLAWALGAKAFYYPEEAGLAFGGPGSSRFLRLEVHYHNPLVITGRRDSSGIRLYYTAA

can ine 349:LRHFNAGIMELGLVYTPVMA IPPKESAFVL TGYCTAKGTOAALPPLGIRIFASQLHTHLT human 343: LRRFNAG I MELGLVYTPVMA IPPRETAF! LTGYCTDKGTQLALPPSGI HIFASQL HTHLT mouse 361:LRRYDAGIMELGLVYTPLMAIPPOETAFVLTGYCTDKGTOMALODSGI HIFASQLHTHLT $r$ at 360: LRPNEAGIMELGLVYTPLMAIPPOETTFVLTGYCTDRGTQMALPKSGIRIFASQLHTHLT equ ine 350: LRRFDAGIMELGLVTPVMAIPPOETAFVL TGYCTDKCTOLALPPSGI HIFASQLHTHLT bov ine 337: LRRFDAGI IELLLAYTPVMA IPPQETPFVL TGYCTDKGTOLALPASGI HI FASQLHTHLT

can ine 409: GTKVVTMLVRDGQEIEIVNRDDHYSPNFGE IRMLKKTVYYPGDVL ITSGTYNTEDKNEA human 403: GRKVVTVLVRDGREWE IVWODNHYSPHFQE IRMLLKWWSVHPGDVL I TSGTYNTEDRELA

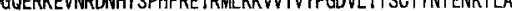
rat 420:GRKVITVLARDGQQREWWRONHYSPHFQE IRMLKNAVTVHOGDVLITSGTYNTENRTMA equine 410: GRKWVIVLARDGREREWWROOHYSPHFQE IRMLKKWSVHPGDVLITSGTYNTEDRKLA bovine 397:GRKVVTVLARDGRETE IVNRONHYSPHFOE IRMLKKVVSVOPGDVL ITSGTYNTEDRRLA canine 469: TVGGLGTQEEMCVYYIHYYPOTOLELCKSHIDPCFLQKYFHL VNRSNLGEYGTCPQASGT human 463: TVGGFGILEEMCVYVHYYPOTOLELCKSAVDAGFLQKYFHL INRFNNEDVGTCPQASmouse 481:TVGGFG ILEEMCVNYVHYYPOTELELGKSAVDDGFLOKYFHWNNRFSSEEVGTCPQASrat 480:IVGGFGILEMCVNYHYPKTELELCKSAVDGALOAYHI WRFGNEEVGTCPAS-

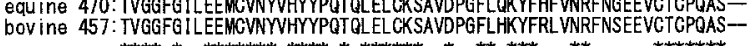

can ine 529:TCPOASGTTCPRASVPEQFASVPWNSFSRVVLKALYDFIPVTVHCNKSSAVRFPGKWDLO



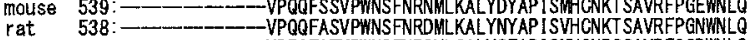
equine 528:-___- - VPEOFATVPWNSFNROVLSALYGFAP I SIHCNRSSAVRFQGDWNLQ bovine 515 :-_ can ine 589:PLPEI! SKLKEPTPRCPT S18190 SSSSLTWWIGGGKV human 567:PLPKVI STLEEPTPQGPTSQGRSPAGPTWVIGGGKG mouse 585:PLPKITSTLEEPTPRCPIRQTOSPANPTVPITTGGRG rat 584:PLPNITSAVEEPDPRCPIROTRGPAGPFWITHGGRH rau ine 574:PLPE II SKLEEPTPRGPASRGRSPAGPTWDIGGGKG bovine 561:PLPEIVSRLEEPTPHCPASGAQSPAGPTVLNISGGKG ***. * . . **.*.**........*..***

Fig. 1. Alignment of deduced amino acid sequences of canine TH (left panel) and DBH (right panel) and other mammalian genes. The deduced amino acid sequence of canine TH was aligned with those of human (NM_000360), mouse (M69200), rat (L22651), and bovine (M36705), and that of canine DBH was aligned with those of human (BC017174), mouse (S50200), rat (L12407), equine (AB029430) and bovine (AF118638). The SNP sites are boxed. The complete nucleotide sequences of canine TH and DBH cDNAs have been submitted to GenBank with the accession numbers of AB097058 and AB097057, respectively. 
Table 1. Genotype, allele frequencies and heterozygosities of polymorphisms on TH gene in five dog breeds

\begin{tabular}{|c|c|c|c|c|c|c|c|c|c|c|c|}
\hline \multirow{3}{*}{$\begin{array}{l}\text { Breed } \\
\text { C97T }\end{array}$} & \multicolumn{6}{|c|}{ Genotype } & \multicolumn{4}{|c|}{ Allele } & \multirow[t]{2}{*}{ H-obs } \\
\hline & $\mathrm{n}$ & $\mathrm{CC}$ & & CT & & TT & & $\mathrm{C}$ & & $\mathrm{T}$ & \\
\hline & 46 & $46(100.0)$ & 0 & $(0.0)$ & & $(0.0)$ & & (100.0) & & $(0.0)$ & - \\
\hline LAB & 41 & $41(100.0)$ & 0 & $(0.0)$ & 0 & $(0.0)$ & 82 & (100.0) & 0 & $(0.0)$ & - \\
\hline MLT & 39 & $39(100.0)$ & 0 & $(0.0)$ & 0 & $(0.0)$ & 78 & (100.0) & 0 & $(0.0)$ & - \\
\hline MS & 25 & $25(100.0)$ & 0 & $(0.0)$ & & $(0.0)$ & 50 & (100.0) & 0 & $(0.0)$ & - \\
\hline SHIBA & 38 & $18 \quad(47.4)$ & 11 & (28.9) & & (23.7) & 47 & $(61.8)$ & 29 & $(38.2)$ & 0.478 \\
\hline Total & 189 & $169 \quad(89.4)$ & 11 & $(5.8)$ & 9 & $(4.8)$ & 349 & (92.3) & 29 & $(7.7)$ & 0.142 \\
\hline G168A & $\mathrm{n}$ & GG & & GA & & $\mathrm{AA}$ & & G & & A & \\
\hline GLD & 46 & $44 \quad(95.7)$ & 1 & $(2.2)$ & 1 & $(2.2)$ & 89 & $(96.7)$ & 3 & (3.3) & 0.064 \\
\hline $\mathrm{LAB}$ & 41 & 31 (75.6) & & (14.6) & & (9.8) & 68 & (82.9) & 14 & (17.1) & 0.287 \\
\hline MLT & 39 & $38 \quad(97.4)$ & 0 & $0.0)$ & 1 & (2.6) & 76 & (97.4) & 2 & (2.6) & 0.051 \\
\hline MS & 25 & $25(100.0)$ & 0 & $0.0)$ & 0 & $(0.0)$ & 50 & (100.0) & 0 & $(0.0)$ & - \\
\hline SHIBA & 38 & $33 \quad(86.8)$ & 5 & (13.2) & 0 & $(0.0)$ & 71 & $(93.4)$ & 5 & (6.6) & 0.125 \\
\hline Total & 189 & 171 (90.5) & 12 & $(6.3)$ & 6 & (3.2) & 354 & (93.7) & 24 & (6.3) & 0.119 \\
\hline G180A & $\mathrm{n}$ & GG & & GA & & $\mathrm{AA}$ & & $\mathrm{G}$ & & A & \\
\hline GLD & 46 & $43 \quad(93.5)$ & 0 & $(0.0)$ & & $(6.5)$ & 86 & (93.5) & 6 & $(6.5)$ & 0.123 \\
\hline LAB & 41 & $32 \quad(78.0)$ & 4 & (9.8) & & (12.2) & 68 & (82.9) & 14 & (17.1) & 0.287 \\
\hline MLT & 39 & $36 \quad(92.3)$ & 2 & (5.1) & & $(2.6)$ & 74 & (94.9) & 4 & $(5.1)$ & 0.099 \\
\hline MS & 25 & $18 \quad(72.0)$ & 6 & $(24.0)$ & 1 & $(4.0)$ & 42 & $(84.0)$ & 8 & (16.0) & 0.274 \\
\hline SHIBA & 38 & $38(100.0)$ & 0 & $0.0)$ & 0 & $(0.0)$ & 76 & (100.0) & 0 & $0.0)$ & - \\
\hline Total & 189 & 167 (88.4) & 12 & (6.3) & 10 & $(5.3)$ & 346 & $(91.5)$ & 32 & $(8.5)$ & 0.155 \\
\hline $\mathrm{C} 264 \mathrm{~T}$ & $\mathrm{n}$ & $\mathrm{CC}$ & & $\mathrm{CT}$ & & ГT & & $\mathrm{C}$ & & $\mathrm{T}$ & \\
\hline GLD & 46 & $40 \quad(87.0)$ & 1 & $(2.2)$ & & (10.9) & 81 & $(88.0)$ & 11 & (12.0) & 0.213 \\
\hline LAB & 41 & $26 \quad(63.4)$ & 10 & $(24.4)$ & & (12.2) & 62 & (75.6) & 20 & (24.4) & 0.373 \\
\hline MLT & 39 & $36 \quad(92.3)$ & 2 & (5.1) & & (2.6) & 74 & (94.9) & 4 & $(5.1)$ & 0.099 \\
\hline MS & 25 & $18 \quad(72.0)$ & 6 & $(24.0)$ & & $(4.0)$ & 42 & $(84.0)$ & 8 & (16.0) & 0.274 \\
\hline SHIBA & 38 & $29 \quad(76.3)$ & 5 & (13.2) & & (10.5) & 63 & (82.9) & 13 & (17.1) & 0.287 \\
\hline Total & 189 & 149 (78.8) & 24 & (12.7) & 16 & $(8.5)$ & 322 & $(85.2)$ & 56 & (14.8) & 0.253 \\
\hline
\end{tabular}

The percentage in each category is shown in parenthesis.

H-obs; observed heterozygosity.

GLD; Golden Retriever, LAB; Labrador Retriever, MLT; Maltese, MS; Miniature Schnauzer.

Four SNPs were identified in the coding region of the $\mathrm{TH}$ gene: a cytosine-to-thymine substitution at the $97^{\text {th }}$ nucleotide (C97T), a guanine-to-adenine substitution at the $168^{\text {th }}$ nucleotide (G168A), a guanine-to-adenine substitution at the $180^{\text {th }}$ nucleotide $(\mathrm{G} 180 \mathrm{~A})$, and a cytosine-to-thymine substitution at the $264^{\text {th }}$ nucleotide (C264T). The SNP of C97T will cause amino acid substitution of arginine to cystein. Two SNPs were identified in the coding region of the DBH gene: a cytosine-to-adenine substitution at the $789^{\text {th }}$ nucleotide (C789A) and an adenine-to-guanine substitution at the $1819^{\text {th }}$ nucleotide $(\mathrm{A} 1819 \mathrm{G})$, which will cause amino acid substitution of asparagine to lysine and serine to glycine, respectively. The positions of these SNPs are shown in Fig. 1.

The genotype and allele frequencies of the TH and DBH polymorphic regions in five dog breeds are presented in Tables 1 and 2. The inter-breed differences with regards to the actual number of genotypes and alleles were highly significant in the four SNPs, based on the $\chi^{2}$ test (G168A; genotype: $\chi^{2}=16.6, \mathrm{df}=6, \mathrm{p}=0.05$ and allele: $\chi^{2}=16.4, \mathrm{df}=3$, $\mathrm{p}<0.01$. G180A; genotype: $\chi^{2}=16.8, \mathrm{df}=6, \mathrm{p}<0.01$ and allele: $\chi^{2}=9.25, \mathrm{df}=3, \mathrm{p}<0.05$. C264T; genotype: $\chi^{2}=18.8$, $\mathrm{df}=8, \mathrm{p}<0.05$ and allele: $\chi^{2}=12.7, \mathrm{df}=4, \mathrm{p}<0.05$. C789A; genotype: $\chi^{2}=81.7, \mathrm{df}=8, \mathrm{p}<0.01$ and allele: $\chi^{2}=103.8, \mathrm{df}=4$, $\mathrm{p}<0.01)$. The C97T and A1819G polymorphisms were seen only in Shibas.

\section{DISCUSSION}

The amplified genes in this study seem to be the actual $\mathrm{TH}$ and DBH genes due to their high homology with other mammalian species (Fig. 1). There is a distinctive insertion of 16 amino acids at the $527^{\text {th }}$ residue from the first methionine only in the dog's DBH gene (Fig. 1). The functional significance of this sequence and whether this insertion is canine-specific or carnivore-specific remain to be solved.

Three silent SNPs and one SNP with amino acid substitution on the TH gene and two SNPs with amino acid substitutions on the DBH gene were found in this study. Most of these SNPs were on the sites that are not conserved across species (Fig. 1). Some research has pointed out that those polymorphisms conserved across species are more likely to be involved in the regulation of vital functions [24, 27, 31]. However, this hypothesis has yet to be confirmed after all 
Table 2. Genotype, allele frequencies and heterozygosities of polymorphisms on DBH gene in five dog breeds

\begin{tabular}{|c|c|c|c|c|c|c|c|c|c|c|c|c|}
\hline \multirow{3}{*}{$\begin{array}{l}\text { Breed } \\
\text { C789A } \\
\text { GLD }\end{array}$} & \multicolumn{7}{|c|}{ Genotype } & \multicolumn{4}{|c|}{ Allele } & \multirow{3}{*}{$\begin{array}{c}\text { H-obs } \\
0 \\
0.490\end{array}$} \\
\hline & $n$ & \multicolumn{2}{|c|}{$\mathrm{CC}$} & \multicolumn{2}{|c|}{$\mathrm{CA}$} & \multicolumn{2}{|r|}{ AA } & \multicolumn{2}{|r|}{$\mathrm{C}$} & \multicolumn{2}{|c|}{ A } & \\
\hline & 45 & 10 & $(22.2)$ & 17 & $(37.8)$ & 18 & (40) & 37 & (41.1) & 53 & $(58.9)$ & \\
\hline LAB & 40 & 5 & (12.5) & 11 & $(27.5)$ & 24 & (60) & 21 & (26.3) & 59 & (73.8) & 0.392 \\
\hline MLT & 38 & 22 & (57.9) & 15 & (39.5) & 1 & (2.6) & 59 & (77.6) & 17 & (22.4) & 0.352 \\
\hline MS & 23 & 17 & (73.9) & 5 & $(21.7)$ & 1 & (4.3) & 39 & (84.8) & 7 & (15.2) & 0.264 \\
\hline SHIBA & 38 & 31 & (81.6) & 7 & (18.4) & 0 & $(0.0)$ & 69 & (90.8) & 7 & $(9.2)$ & 0.169 \\
\hline Total & 184 & 85 & $(46.2)$ & 55 & (29.9) & 44 & (23.9) & 225 & (61.1) & 143 & $(38.9)$ & 0.476 \\
\hline A1819G & $\mathrm{n}$ & \multicolumn{2}{|c|}{$\mathrm{AA}$} & \multicolumn{2}{|c|}{ GA } & \multicolumn{2}{|c|}{ GG } & \multicolumn{2}{|c|}{ A } & \multicolumn{2}{|c|}{$\mathrm{G}$} & \\
\hline GLD & 20 & 20 & (100.0) & 0 & $(0.0)$ & 0 & $(0.0)$ & 40 & $(100.0)$ & 0 & $(0.0)$ & - \\
\hline $\mathrm{LAB}$ & 20 & 20 & $(100.0)$ & 0 & $(0.0)$ & 0 & $(0.0)$ & 40 & $(100.0)$ & 0 & $(0.0)$ & - \\
\hline MLT & 20 & 20 & (100.0) & 0 & $(0.0)$ & 0 & $(0.0)$ & 40 & $(100.0)$ & 0 & $(0.0)$ & - \\
\hline MS & 20 & 20 & $(100.0)$ & 0 & $(0.0)$ & 0 & $(0.0)$ & 40 & $(100.0)$ & 0 & $(0.0)$ & _- \\
\hline SHIBA & 39 & 10 & $(25.6)$ & 12 & (30.8) & 17 & $(43.6)$ & 32 & $(41.0)$ & 46 & $(59.0)$ & 0.490 \\
\hline Total & 119 & 90 & (75.6) & 12 & (10.1) & 17 & (14.3) & 192 & (80.7) & 46 & (19.3) & 0.313 \\
\hline
\end{tabular}

The percentage in each category is shown in parenthesis.

H-obs; observed heterozygosity.

GLD; Golden Retriever, LAB; Labrador Retriever, MLT; Maltese, MS; Miniature Schnauzer.

SNPs are identified and analyzed for their relationship to personality and/or psychiatric disorders. The effect of silent SNPs should also be analyzed [4]. Since the locations of all SNPs identified in this study were different from those of SNPs in human TH and DBH genes, possible structural and functional changes derived from these SNPs should be examined as have been reported for human genes $[7,33$, 34].

With regards to the breed differences of these SNPs, C97T on the TH gene and A1819G on the DBH gene are only found in Shibas. This may imply that Shiba is a lessdomesticated canine breed with particular genetic variety based upon the finding from our study and the previous report [28] in which the Shiba was genetically categorized more closely to the wolf than any other breed analyzed in this study. The alleles of 168A and 264T on the TH gene are found in the Labrador Retriever with relatively high frequency. According to the research of Hart and Hart [11], only the Labrador Retriever ranked relatively low in 'demand for affection' and 'general activity' character traits, and higher in 'ease of housebreaking' compared to the other four breeds in this study. At G180A, the Labrador Retriever and Miniature Schnauzer have relatively more A alleles compared to the other breeds. These two breeds were shown to rank higher in 'territorial defense' in the same study. At C789A, the ratio of allele frequency of the Golden and Labrador Retrievers to other breeds is reversed. Similarly, Retrievers were shown to rank lower in 'excitability', 'watchdog barking', 'dominance over owner', 'snapping at children', 'aggression toward other dogs', 'destructiveness' and 'excessive barking', and rank higher in 'obedience trainig' compared to the other three breeds in the previous study [11]. The relationship between our study and the research about breed difference of behavioral traits should be examined in near the future.

Although the draft sequence of canine genome was unveiled on the website of National Center for Biotechnol- ogy Information (http://www.ncbi.nlm.nih.gov/genome/ guide/dog/) on July 2004, only a few genetic markers that will be related to canine behavioral traits have been listed up $[12,14,15,19,20,25,26,37]$. This situation is possibly a result of the lack of researchers devoted to this area of science. However, the dog is an ideal animal for this type of research, since they live in simpler social systems than humans and can express more emotions than experimental rodents, such as rat and mouse. This kind of research will lead us to reveal not only the genetic diversity of canine breeds but also the genetic background of canine behavioral traits.

ACKNOWLEDGMENTS. We are thankful to DVMs Norio Kogure, Kazue Igarashi, Hisao Imoto, Reiko Usui, Keiko Uchida, Tetsuyasu Uno, Ayako Kakinuma, Shoji Satoh, Masami Takebe, Makoto Tatematsu, and Kaori Murata and the staff of their veterinary hospitals for their kind cooperation in collecting blood samples from dogs. This work was supported by grants-in-aid for scientific research from the Ministry of Education, Science, Sports, Culture and Technology.

\section{REFERENCES}

1 Arinami, T., Ishiguro, H. and Onaivi, E. S. 2000. Polymorphisms in genes involved in neurotransmission in relation to smoking. Eur. J. Pharmacol. 410: 215-226.

2 Benjamin, J., Li, L., Patterson, C., Greenberg, B. D., Murphy, D. L. and Hamer, D. H. 1996. Population and familial association between the D4 dopamine receptor gene and measures of Novelty Seeking. Nature Genet. 12: 81-84.

3 Breen, M., Hitte, C., Lorentzen, T. D., Thomas, R., Cadieu, E., Sabacan, L., Scott, A., Evanno, G., Parker, H. G., Kirkness, E. F., Hudson, R., Guyon, R., Mahairas, G. G., Gelfenbeyn, B., Fraser, C. M., Andre, C., Galibert, F. and Ostrander, E. A. 2004. An integrated 4249 marker FISH/RH map of the canine genome. BMC Genomics 5: 65. 
4 Cartegni, L., Chew, S. L. and Krainer, A. R. 2002. Listening to silence and understanding nonsense: exonic mutations that affect splicing. Nat. Rev. Genet. 3: 285-298.

5 Comings, D. E. and MacMurray, J. P. 2000. Molecular heterosis: a review. Mol. Genet. Metab. 71: 19-31.

6 Craddock, N., Dave, S. and Greening, J. 2001. Association studies of bipolar disorder. Bipolar Disord. 3: 284-298.

7 Cubells, J. F. and Zabetian, C. P. 2004. Human genetics of plasma dopamine beta-hydroxylase activity: applications to research in psychiatry and neurology. Psychopharmacology (Berl) 174: 463-476.

8 Daly, G., Hawi, Z., Fitzgerald, M. and Gill, M. 1999. Mapping susceptibility loci in attention deficit hyperactivity disorder: preferential transmission of parental alleles at DAT1, DBH and DRD5 to affected children. Mol. Psychiat. 4: 192-196.

9 Ebstein, R. P., Novick, O., Umansky, R., Priel, B., Osher, Y., Blaine, D., Bennett, E. R., Nemanov, L., Katz, M. and Belmaker, R. H. 1996. Dopamine D4 receptor (D4DR) exon III polymorphism associated with the human personality trait of Novelty Seeking. Nature Genet. 12: 78-80.

10 Guyon, R., Lorentzen, T. D., Hitte, C., Kim, L., Cadieu, E., Parker, H. G., Quignon, P., Lowe, J. K., Renier, C., Gelfenbeyn, B., Vignaux, F., DeFrance, H. B., Gloux, S., Mahairas, G. G., Andre, C., Galibert, F. and Ostrander, E. A. 2003. A 1$\mathrm{Mb}$ resolution radiation hybrid map of the canine genome. Proc. Natl. Acad. Sci. U. S. A. 100: 5296-5301.

11 Hart, B. L. and Hart, L. A. 1988. The perfect puppy, W. H. Freeman and Company, New York.

12 Hashizume, C., Masuda, K., Momozawa, Y., Kikusui, T., Takeuchi, Y. and Mori, Y. 2005. Identification of an arginineto-cysteine substitution caused by a single nucleotide polymorphism in the canine monoamine oxidase B gene. J. Vet. Med. Sci. 67: 199-201.

13 Healy, D. G., Abou-Sleiman, P. M., Ozawa, T., Lees, A. J., Bhatia, K., Ahmadi, K. R., Wullner, U., Berciano, J., Moller, J. C., Kamm, C., Burk, K., Barone, P., Tolosa, E., Quinn, N., Goldstein, D. B. and Wood, N. W. 2004. A functional polymorphism regulating dopamine beta-hydroxylase influences against Parkinson's disease. Ann Neurol. 55: 443-446.

14 Ito, H., Nara, H., Inoue-Murayama, M., Shimada, M. K., Koshimura, A., Ueda, Y., Kitagawa, H., Takeuchi, Y., Mori, Y., Murayama, Y., Morita, M., Iwasaki, T., Ota, K., Tanabe, Y. and Ito, S. 2004. Allele Frequency Distribution of the Canine Dopamine Receptor D4 Gene Exon III and I in 23 Breeds. $J$. Vet. Med. Sci. 66: 815-820.

15 Jeoung, D., Myeong, H., Lee, H., Ha, J., Galibert, F., Hitte, C. and Park, C. 2000. A SINE element in the canine D2 dopamine receptor gene and its chromosomal location. Anim. Genet. 31: 334-335.

16 Leboyer, M., Malafosse, A., Boularand, S., Campion, D., Gheysen, F., Samolyk, D., Henriksson, B., Denise, E., des Lauriers, A. and Lepine, J. P. 1990. Tyrosine hydroxylase polymorphisms associated with manic-depressive illness. Lancet 335: 1219.

17 Lesch, K. P. and Merschdorf, U. 2000. Impulsivity, aggression, and serotonin: a molecular psychobiological perspective. Behav. Sci. Law 18: 581-604.

18 Lim, L. C., Gurling, H., Curtis, D., Brynjolfsson, J., Petursson, H. and Gill, M. 1993. Linkage between tyrosine hydroxylase gene and affective disorder cannot be excluded in two of six pedigrees. Am. J. Med. Genet. 48: 223-228.

19 Masuda, K., Hashizume, C., Kikusui, T., Takeuchi, Y. and Mori, Y. 2004. Breed differences in genotype and allele fre- quency of catechol O-methyltransferase gene polymorphic regions in dogs. J. Vet. Med. Sci. 66: 183-187.

20 Masuda, K., Hashizume, C., Ogata, N., Kikusui, T., Takeuchi, Y. and Mori, Y. 2004. Sequencing of canine 5-hydroxytriptamine receptor (5-HTR) 1B, 2A, 2C genes and identification of polymorphisms in the 5-HTR1B gene. J. Vet. Med. Sci. 66: $965-972$.

21 McKinney, E. F., Walton, R. T., Yudkin, P., Fuller, A., Haldar, N. A., Mant, D., Murphy, M., Welsh, K. I. and Marshall, S. E. 2000. Association between polymorphisms in dopamine metabolic enzymes and tobacco consumption in smokers. Pharmacogenetics 10: 483-491.

22 Meloni, R., Laurent, C., Campion, D., Ben Hadjali, B., Thibaut, F., Dollfus, S., Petit, M., Samolyk, D., Martinez, M., Poirier, M. F. and et al. 1995. A rare allele of a microsatellite located in the tyrosine hydroxylase gene found in schizophrenic patients. C. R. Acad. Sci. III 318: 803-809.

23 Munafo, M. R., Clark, T. G., Moore, L. R., Payne, E., Walton, R. and Flint, J. 2003. Genetic polymorphisms and personality in healthy adults: a systematic review and meta-analysis. Mol. Psychiat. 8: 471-484.

24 Murphy, D. L., Lerner, A., Rudnick, G. and Lesch, K. P. 2004. Serotonin transporter: gene, genetic disorders, and pharmacogenetics. Mol. Interv. 4: 109-123.

25 Nara, H., Inoue-Murayama, M., Koshimura, A., Sugiyama, A., Murayama, Y., Maejima, M., Ueda, Y., Ito, H., Randi, E., Kim, H.-S., Ha, J.-H., Kitagawa, H., Takeuchi, Y., Mori, Y., Iwasaki, T., Morita, M. and Ota, K. 2005. Novel polymorphism of the canine dopamine receptor D4 gene intron II region. Anim. Sci. J. 76: 81-86.

26 Niimi, Y., Inoue-Murayama, M., Murayama, Y., Ito, S. and Iwasaki, T. 1999. Allelic variation of the D4 dopamine receptor polymorphic region in two dog breeds, Golden retriever and Shiba. J. Vet. Med. Sci. 61: 1281-1286.

27 Ozaki, N., Goldman, D., Kaye, W. H., Plotnicov, K., Greenberg, B. D., Lappalainen, J., Rudnick, G. and Murphy, D. L. 2003. Serotonin transporter missense mutation associated with a complex neuropsychiatric phenotype. Mol. Psychiatry 8: 895, 933-896.

28 Parker, H. G., Kim, L. V., Sutter, N. B., Carlson, S., Lorentzen, T. D., Malek, T. B., Johnson, G. S., DeFrance, H. B., Ostrander, E. A. and Kruglyak, L. 2004. Genetic structure of the purebred domestic dog. Science 304: 1160-1164.

29 Persson, M. L., Wasserman, D., Jonsson, E. G., Bergman, H., Terenius, L., Gyllander, A., Neiman, J. and Geijer, T. 2000. Search for the influence of the tyrosine hydroxylase (TCAT)(n) repeat polymorphism on personality traits. Psychiat. Res. 95: $1-8$.

30 Prasad, S., Semwal, P., Deshpande, S., Bhatia, T., Nimgaonkar, V. L. and Thelma, B. K. 2002. Molecular genetics of schizophrenia: past, present and future. J. Biosci. 27: 35-52.

31 Rebbeck, T. R., Spitz, M. and Wu, X. 2004. Assessing the function of genetic variants in candidate gene association studies. Natute Rev. Genet. 5: 589-597.

32 Roman, T., Schmitz, M., Polanczyk, G. V., Eizirik, M., Rohde, L. A. and Hutz, M. H. 2002. Further evidence for the association between attention-deficit/hyperactivity disorder and the dopamine-beta-hydroxylase gene. Am. J. Med. Genet. 114: $154-158$.

33 Royo, M., Daubner, S. C. and Fitzpatrick, P. F. 2005. Effects of mutations in tyrosine hydroxylase associated with progressive dystonia on the activity and stability of the protein. Proteins 58: $14-21$. 
34 Royo, M., Fitzpatrick, P. F. and Daubner, S. C. 2005. Mutation of regulatory serines of rat tyrosine hydroxylase to glutamate: effects on enzyme stability and activity. Arch. Biochem. Biophys. 434: 266-274.

35 Serretti, A., Macciardi, F., Verga, M., Cusin, C., Pedrini, S. and Smeraldi, E. 1998. Tyrosine hydroxylase gene associated with depressive symptomatology in mood disorder. Am. J. Med. Genet. 81: $127-130$.

36 Sharma, P., Hingorani, A., Jia, H., Ashby, M., Hopper, R., Clayton, D. and Brown, M. J. 1998. Positive association of tyrosine hydroxylase microsatellite marker to essential hypertension. Hypertension 32: 676-682.

37 van den Berg, L., Imholz, S., Versteeg, S. A., Leegwater, P. A., Zijlstra, C., Bosma, A. A. and van Oost, B. A. 2004. Isolation and characterization of the canine serotonin receptor $1 \mathrm{~B}$ gene (htr1B). Gene 326: 131-139.

38 Wei, J., Ramchand, C. N. and Hemmings, G. P. 1995. Association of polymorphic VNTR region in the first intron of the human TH gene with disturbances of the catecholamine pathway in schizophrenia. Psychiat. Genet. 5: 83-88. 